\title{
Synthesis and Structural Studies of Mixed Ligand Complexes of Transition Metals with Pyruvic Acid Semicarbazone and Acetone Semicarbazone
}

\author{
P. R. SHIRODE ${ }^{1}$, R. K. AGRAWAL ${ }^{1}$, A. M. JAIN ${ }^{1}$ and P. M. YEOLE ${ }^{2}$ \\ ${ }^{1}$ Department of Chemistry, Pratap College, Amalner, India \\ ${ }^{2}$ R.L.College, Parola North Maharashtra University. Jalgaon, Maharashtra-425401, India \\ prshirodepca@gmail.com
}

Received 20 September 2014 / Accepted 17 October 2014

\begin{abstract}
The mixed ligand complexes of the type $\left[\mathrm{ML}_{1} \mathrm{~L}_{2}\right] \mathrm{Cl}_{2}$, where $\mathrm{M}=\mathrm{Mn}(\mathrm{II}), \mathrm{Fe}(\mathrm{III}), \mathrm{Co}(\mathrm{II})$, $\mathrm{Ni}(\mathrm{II}), \mathrm{Cu}(\mathrm{II}) \mathrm{L}_{1}=$ pyruvic acid semicarbazone (PYSC) $\mathrm{L}_{2}=$ acetone semicarbazone (ACSC). These complexes have been synthesized by the reactions of metal chlorides with two different semicarbazone in 1:1:1 molar ratios. The resulting products have been characterized on the basis of elemental analysis, magnetic measurement, IR and electronic spectra, conductivity measurement, thermalanalysis, antimicrobialactivities. The metal complexes show ratio 1:1:1 with metal, ligand $\mathrm{L}_{1}$ and ligand $\mathrm{L}_{2}$. The ligands are bonded through oxygen and nitrogen to metal ion.
\end{abstract}

Keywords: Mixed ligand complexes, Acetone semicarbazone, Pyruvic acid semicarbazone, Thermal analysis, Antimicrobial analysis

\section{Introduction}

Semicarbazone plays a key role in organic and biological chemistry. The semicarbazone linkage is an important functional group due to its extensive presence in natural products, pharmaceutical compounds and synthetic polymers. The most common traditional method for the synthesis of the semicarbazone derivative is that semicarbazide hydrochloride on treatment with pyruvic acid or acetone gives semicarbazone derivative. Transition metal ions are playing an important role in biological processes in the human body ${ }^{1,2}$. For example, nickel(II), copper(II) and zinc(II) ions are the most abundant transition metals in humans. They are found either at the active sites or as structural components of a good number of enzymes ${ }^{3,4}$. The study of the coordination chemistry of biologically important metal ions with mixed ligands has been one of the recent developments in the field of bioinorganic chemistry. But, studies on the antimicrobial activities of their metal complexes are rare in literature. Metal complexes containing nitrogen and sulphur donors have been proved to be potential antibacterial and fungal agents ${ }^{5}$ as well as component of several vitamins and $\operatorname{drugs}^{6,7}$. 
In this paper we reporting the synthesis of mixed ligand complexes of transition metals $\mathrm{Mn}(\mathrm{II}), \mathrm{Fe}(\mathrm{III}), \mathrm{Co}(\mathrm{II}), \mathrm{Ni}(\mathrm{II})$ and $\mathrm{Cu}(\mathrm{II})$ with pyruvic acid semicarbazone and acetone semicarbazone as ligands.

\section{Objectives and scope of the present work}

There has been considerable interest in the studies of semicarbazone due to their coordination modes when bound to metal. The wide applications and structural diversity of metal complexes of semicarbazone encouraged us to synthesize the tridentate ONO-donor semicarbazone and their metal complexes. Metal complexes of pyruvic acid semicarbazone, semicarbazone of acetone, acetophenone, benzaldehyde, cyclohexanone, o-hydroxy acetophanone and their derivatives as ligands with transition metal as $\left(\mathrm{ML}_{2}\right)$ complexes have been already reported in early days.

Due to good chelating ability, the present work is mainly concerned on the studies of two novel semicarbazone, pyruvic acid semicarbazone $\left[\mathrm{L}_{1}\right]$ and acetone semicarbazone $\left[\mathrm{L}_{2}\right]$. The compositions of these semicarbazone were determined by the $\mathrm{CHN}$ analyses. For the characterization of these compounds we have used IR and UV spectral studies. We have synthesized iron(III) complexes of these semicarbazone in the ratio 1:1:1

\section{Experimental}

All chemicals used were of research grade chemicals of make Loba, S-D Fine, E-Merck etc. The amount of metal was determined volumetrically by using EDTA. Ammonium thiocynate was used as indicator for Fe(III). Erich Rome Black T was used for Mn(II). While xylenol orange for $\mathrm{Co}(\mathrm{II})$, mureoxide was used for $\mathrm{Ni}(\mathrm{II})$ and $\mathrm{Cu}(\mathrm{II})$.

Carbon, hydrogen and nitrogen analysis were carried from SAIF, Mumbai. Specific conductance were measured at room temperature in DMF by a Systronics direct reading 304 conductivity meter using a glass conductivity cell having a cell constant. IR spectra were taken from Perkin Elmer IR Spectrophotometer from Department of Physics, Pratap College, Amalner, India.

\section{Synthesis of ligands}

Ligands $\mathrm{L}_{1}$ and $\mathrm{L}_{2}$ were prepared. The methods of their preparation are given below.

\section{Ligand: $L_{1}=$ Pyruvic acid semicarbazone}

$2 \mathrm{~g}$ of Semicarbazide hydrochloride and $3 \mathrm{~g}$ of sodium acetate was taken in a $100 \mathrm{~mL}$ beaker then $20-30 \mathrm{~mL}$ diluted water was added and continuously stirred to obtain a clear solution of mixture of semicarbazide hydrochloride and sodium acetate, the solution was filtered and placed in an ice bath. $2 \mathrm{~mL}$ of pyruvic acid was taken in a test tube and cooled it in ice bath. This ice cooled solution of pyruvic acid was added drop wise very slowly in a ice cooled solution of mixture of sodium acetate and semicarbazide hydrochloride with constant stirring. The reaction mixture was stirred for another half an hour to separate out white precipitate of pyruvic acid semicarbazone. Recrystallized the crude product from hot water, dried and then melting point and yield was recorded (Scheme 1, Table 1).

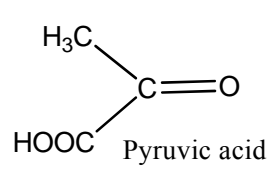

Semicarbazide $\mathrm{NH}_{2}$

Scheme 1<smiles>CC(=NNC(N)=O)C(=O)O</smiles> 


\section{Ligand: $L_{2}=$ Acetone semicarbazone}

$2 \mathrm{~g}$ of semicarbazide of hydrochloride and $3 \mathrm{~g}$ of crystallized sodium acetate were dissolved in about $25-30 \mathrm{~mL}$ of distilled water in a hard glass test tube, cooled in ice bath, to this solution $2 \mathrm{~mL}$ of acetone was added drop by drop with constant stirring for half an hour. White crystals of the semicarbazone derivative were separate out from the solution. The crystals are filtered and recrystallized from ethyl alcohol, dried and then melting point and yield was recorded (Scheme 2).<smiles>CC(C)=O</smiles>

Acetone<smiles></smiles>

Semicarbazide

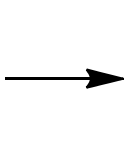

Scheme 2

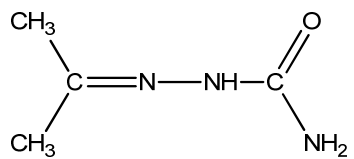

Acetone semicarbazone

Table 1. Physical properties of ligands

\begin{tabular}{cccccc}
\hline $\begin{array}{c}\text { Name of the } \\
\text { ligand }\end{array}$ & $\begin{array}{c}\text { Color and } \\
\text { nature }\end{array}$ & $\begin{array}{c}\text { Method of } \\
\text { purification }\end{array}$ & $\begin{array}{c}\text { M.P. }{ }^{\circ} \mathrm{C} \\
\text { (observed) reported }\end{array}$ & $\begin{array}{c}\text { Mol. } \\
\text { wt }\end{array}$ & $\begin{array}{c}\text { Molecular } \\
\text { formula }\end{array}$ \\
\hline $\begin{array}{c}\text { Pyruvic acid } \\
\text { semicarbazon }\end{array}$ & $\begin{array}{c}\text { White shining } \\
\text { crystals }\end{array}$ & $\begin{array}{c}\text { Recrystallization } \\
\text { from water }\end{array}$ & $\begin{array}{c}215 \\
(214)\end{array}$ & 145 & $\mathrm{C}_{4} \mathrm{H}_{7} \mathrm{~N}_{3} \mathrm{O}_{3}$ \\
\hline $\begin{array}{c}\text { Acetone } \\
\text { semicarbazone }\end{array}$ & $\begin{array}{c}\text { White shining } \\
\text { crystals }\end{array}$ & $\begin{array}{c}\text { Recrystallization } \\
\text { from } \mathrm{CCl}_{4}\end{array}$ & $\begin{array}{c}190 \\
(188)\end{array}$ & 115 & $\mathrm{C}_{4} \mathrm{H}_{9} \mathrm{~N}_{3} \mathrm{O}$ \\
\hline
\end{tabular}

Synthesis of complexes

Preparation of $M\left(L_{1}\right)_{2}$ and $M\left(L_{2}\right)_{2}$ complexes

Aqueous $(25 \mathrm{~mL}, 0.01 \mathrm{M})$ solution of metal chloride was mixed slowly with hot aqueous $25 \mathrm{~mL}$ $(0.02 \mathrm{M})$ solution of the pyruvic semicarbazone $\left(\mathbf{L}_{1}\right)$ with constant stirring. The reaction mixture was heated in water bath for three hour. Then the reaction was stirred for further one hour after which colored solid product was obtained, which was then washed with ethanol and dried in air. Similarly, the complexes of $\mathrm{Mn}(\mathrm{II}), \mathrm{Fe}(\mathrm{III}), \mathrm{Co}(\mathrm{II}), \mathrm{Ni}(\mathrm{II})$ and $\mathrm{Cu}(\mathrm{II})$ were prepared by mixing solution of corresponding metal chlorides and semicarbazone ligand $\left(\mathbf{L}_{2}\right)$ in 1:2 molar ratio respectively.

Preparation of mixed ligand complexes the type $M L_{1} L_{2}$

To a $20 \mathrm{~mL}(0.02 \mathrm{M})$ aqueous solution of manganese chloride, a mixture of $20 \mathrm{~mL}(0.02 \mathrm{M})$ aqueous solution of pyruvic semicarbazone and $20 \mathrm{~mL}(0.02 \mathrm{M})$ solution of acetone semicarbazone were added slowly with constant stirring. This reaction mixture was refluxed in water bath for 3 to 4 hours and then $10 \%$ sodium hydroxide was added to adjust the $\mathrm{pH}$ to about 7 to 7.5. The $\mathrm{pH}$ of the solution was tested by $\mathrm{pH}$ paper. In case of complexes of cobalt and copper the $\mathrm{pH}$ of the reaction mixture must not exceed 7.5 unless the color of the complexes darken more and more to give a black color. The solution was stirred further for one hour, cooled to separate the solid coloured complex. It was filtered, washed with ethanol and dried in air.

By using similar procedure other complexes were prepared by mixing aqueous solution of metal chlorides of $\mathrm{Cr}(\mathrm{III}), \mathrm{Mn}(\mathrm{II}), \mathrm{Fe}(\mathrm{III}), \mathrm{Co}(\mathrm{II}), \mathrm{Ni}(\mathrm{II}), \mathrm{Cu}(\mathrm{II})$ with pyruvic semicarbazone and acetone semicarbazone in the ratio $1: 1: 1$.

\section{Results and Discussion}

The reactions of metal chlorides with pyruvic acid semicarbazone and acetone semicarbazone of acetone in the 1:1:1 molar ratio results in the formation mixed ligand complexes. 
The resulting complexes were having different colors as given in the Table 2. They are insoluble in chloroform, carbon tetrachloride, methanol, ethanol but soluble in DMF. The properties of metal complexes are indicated in Table 3 . The conductance of the complexes are very low (1.50 to $\left.14.02 \Omega^{-1} \mathrm{~cm}^{2} \mathrm{~mol}^{-1}\right)$ indicating their non-electrolyte nature.

Table 2. Characterization data of the complexes

\begin{tabular}{|c|c|c|c|c|c|c|c|c|}
\hline $\begin{array}{l}\text { S. } \\
\text { No. }\end{array}$ & $\begin{array}{l}\text { Ligand/ } \\
\text { complex }\end{array}$ & Color & $\begin{array}{l}\text { Mole. } \\
\text { Wt. }\end{array}$ & $\begin{array}{l}\% \text { Yield } \\
\text { of the } \\
\text { compd. }\end{array}$ & $\begin{array}{l}\% \text { of metal } \\
\text { (calculated) }\end{array}$ & $\begin{array}{l}\% \\
\mathrm{C}\end{array}$ & $\begin{array}{c}\% \\
\mathrm{H}\end{array}$ & $\begin{array}{l}\% \\
\mathrm{~N}\end{array}$ \\
\hline 1 & $\mathrm{Mn}(\mathrm{PYSC})_{1}(\mathrm{ACSC})_{1}$ & Black & 403.98 & 59.80 & $\begin{array}{c}13.61 \\
(13.34)\end{array}$ & $\begin{array}{c}23.76 \\
(23.52)\end{array}$ & $\begin{array}{c}4.45 \\
(4.47)\end{array}$ & $\begin{array}{c}20.79 \\
(20.69)\end{array}$ \\
\hline 2 & $\mathrm{Fe}(\mathrm{PYSC})_{1}(\mathrm{ACSC})_{1}$ & Orange & 440.35 & 62.05 & $\begin{array}{c}12.68 \\
(12.07)\end{array}$ & $\begin{array}{c}21.80 \\
(21.71)\end{array}$ & $\begin{array}{c}4.08 \\
(4.06)\end{array}$ & $\begin{array}{l}19.08 \\
(18.97)\end{array}$ \\
\hline 3 & $\mathrm{Co}(\mathrm{PYSC})_{1}(\mathrm{ACSC})_{1}$ & $\begin{array}{l}\text { Dark } \\
\text { green }\end{array}$ & 407.93 & 63.06 & $\begin{array}{c}14.44 \\
(13.96)\end{array}$ & $\begin{array}{c}23.53 \\
(23.61)\end{array}$ & $\begin{array}{c}4.41 \\
(4.42)\end{array}$ & $\begin{array}{c}20.59 \\
(20.40)\end{array}$ \\
\hline 4 & $\mathrm{Ni}(\mathrm{PYSC})_{1}(\mathrm{ACSC})_{1}$ & $\begin{array}{l}\text { Faint } \\
\text { green }\end{array}$ & 407.63 & 67.02 & $\begin{array}{c}14.44 \\
(14.49)\end{array}$ & $\begin{array}{c}23.53 \\
(23.50)\end{array}$ & $\begin{array}{c}4.41 \\
(4.35)\end{array}$ & $\begin{array}{c}20.59 \\
(20.51)\end{array}$ \\
\hline 5 & $\mathrm{Cu}(\mathrm{PYSC})_{1}(\mathrm{ACSC})_{1}$ & $\begin{array}{l}\text { Dark } \\
\text { green }\end{array}$ & 412.54 & 60.02 & $\begin{array}{c}15.40 \\
(15.24)\end{array}$ & $\begin{array}{c}23.57 \\
(23.41) \\
\end{array}$ & $\begin{array}{c}4.36 \\
(4.37) \\
\end{array}$ & $\begin{array}{r}20.36 \\
(20.31) \\
\end{array}$ \\
\hline
\end{tabular}

Table 3. IR spectra $\left(\mathrm{cm}^{-1}\right)$ bands of the parent and mixed ligand transition metal complexes

\begin{tabular}{ccccccc}
\hline S.No. & Name of the complex & $v$ - $(\mathrm{OH})$ from $\mathrm{H}_{2} \mathrm{O}$ & $v$ - $(\mathrm{COOH})$ & $v(\mathrm{C}=\mathrm{O})$ & $v(\mathrm{C}=\mathrm{N})$ & $v(\mathrm{~N}-\mathrm{N})$ \\
\hline 1 & $\mathrm{Mn}(\mathrm{PYSC})_{1}(\mathrm{ACSC})_{1}$ & 3175 & 2360 & 1698 & 1582 & 1197 \\
2 & $\mathrm{Fe}(\mathrm{PYSC})_{1}(\mathrm{ACSC})_{1}$ & 3328 & 2360 & 1597 & 1496 & 1120 \\
3 & $\mathrm{Co}(\mathrm{PYSC})_{1}(\mathrm{ACSC})_{1}$ & 2923 & 2359 & 1699 & 1540 & 1111 \\
4 & $\mathrm{Ni}(\mathrm{PYSC})_{1}(\mathrm{ACSC})_{1}$ & 3361 & 2360 & 1647 & 1547 & 1120 \\
5 & $\mathrm{Cu}(\mathrm{PYSC})_{1}(\mathrm{ACSC})_{1}$ & - & 2360 & 1655 & 1583 & 1187 \\
\hline
\end{tabular}

The TLC of the mixed ligand complexes exhibit single spots with $\mathrm{R}_{\mathrm{f}}$ values being intermediate of the two corresponding symmetrical bis-complexes indicating that these are mixed ligand complexes rather than a mixture of two corresponding bis-complexes. From the magnetic moments these complexes shows octahedral geometry.

In the IR spectra of the mixed ligand complexes the bands at $1583-1540 \mathrm{~cm}^{-1}$ may be assigned to the symmetric and asymmetric $\mathrm{v}(\mathrm{C}=\mathrm{N})$ vibrations. A strong band in the region $1699-1647 \mathrm{~cm}^{-1}$ are due to $\mathrm{v}(\mathrm{C}=\mathrm{O})$ groups. On complex formation, the position of these bands is shifted toward lower side as compared to the metal free ligand. This indicates that the coordination takes place through the nitrogen and oxygen atom of the $(\mathrm{C}=\mathrm{N})$ and $(\mathrm{C}=\mathrm{O})$ groups. A band in the region $1197-1120 \mathrm{~cm}^{-1}$ is due to N-N bond. A broad band appears in the region at $3361-3175 \mathrm{~cm}^{-1}$ for complexes be attributed to the coordinated water molecule. Thermogravemetric analysis shows presence of one water molecules in the complexes supporting the octahedral nature of complexes

$\mathrm{Mn}(\mathrm{II})$ complexes show two bands at $11405,25839 \mathrm{~cm}^{-1}$ and a weak band in the region $34129 \mathrm{~cm}^{-1}$ for octahedral geometry. In the spectrum of the Fe(III) complex bands at 11594 $\mathrm{cm}^{-1}$ may be assigned to the ${ }^{6} \mathrm{~A}_{1 \mathrm{~g}} \rightarrow{ }^{4} \mathrm{~T}_{1 \mathrm{~g}}$ (E) transition. These lower energy band at 26851 may be due to a splitting of the ${ }^{4} \mathrm{~T}_{1} \mathrm{~g}$ term. Another band appears at $32051 \mathrm{~cm}^{-1}$ which can be assigned to the ${ }^{6} \mathrm{~A}_{1 \mathrm{~g}} \rightarrow 4 \mathrm{~T}_{2 \mathrm{~g}}$ transition. The spectrum suggests distorted octahedral geometry with D4h symmetry. The Co(II) complex displays a charge transfer band at $30193 \mathrm{~cm}^{-1}$ and two d-d bands at 11,984 and $14388 \mathrm{~cm}^{-1}$ are due to the ${ }^{4} \mathrm{~T}_{1 \mathrm{~g}} \rightarrow{ }^{4} \mathrm{~A}_{2 \mathrm{~g}}\left(\mathrm{v}_{2}\right)$ and ${ }^{4} \mathrm{~T}_{1 \mathrm{~g}}(\mathrm{~F}) \rightarrow{ }^{4} \mathrm{~T}_{1 \mathrm{~g}}(\mathrm{P})$ 
$\left(v_{3}\right)$ transitions, respectively, in an octahedral geometry around the Co(II) ion. The electronic spectrum of $\mathrm{Ni}(\mathrm{II})$ complex exhibits three bands in the region 21,000, 15267 and $11778 \mathrm{~cm}^{-1}$ which are assigned to the ${ }^{3} \mathrm{~A}_{2 \mathrm{~g}}(\mathrm{~F}) \rightarrow{ }^{3} \mathrm{~T}_{1 \mathrm{~g}}(\mathrm{P}),{ }^{3} \mathrm{~A}_{2 \mathrm{~g}}(\mathrm{~F}) \rightarrow{ }^{3} \mathrm{~T}_{1 \mathrm{~g}}(\mathrm{~F})$ and ${ }^{3} \mathrm{~A}_{2 \mathrm{~g}}(\mathrm{~F}) \rightarrow{ }^{3} \mathrm{~T}_{2 \mathrm{~g}}(\mathrm{~F})$ transitions respectively, indicating an octahedral geometry around the $\mathrm{Ni}(\mathrm{II})$ ion. The octahedral geometry of $\mathrm{Co}$ (II) and $\mathrm{Ni}$ (II) complexes is further supported by the value of the $v_{2} / v_{1}$ ratio, which are 1.316 and 1.296 . The $\mathrm{Cu}(\mathrm{II})$ complexes display three prominent bands. Low intensity broad band at $11862 \mathrm{~cm}^{-1}$ was assigned as $10 \mathrm{Dq}$ band corresponding to ${ }^{2} \mathrm{E}_{\mathrm{g}} \rightarrow{ }^{2} \mathrm{~T}_{2 \mathrm{~g}}$ transition ${ }^{9}$. In addition, there was high intensity band at $25125 \mathrm{~cm}^{-1}$. This band is due to symmetry forbidden ligand $\rightarrow$ metal charge transfer transition ${ }^{10}$. The band above $28089 \mathrm{~cm}^{-1}$ was assigned as ligand band. Therefore distorted octahedral geometry around $\mathrm{Cu}(\mathrm{II})$ ion was suggested on the basis of electronic spectra ${ }^{11}$.

\section{Antibacterial activity}

The biological activity of the investigated semicarbazone and their mixed ligand complexes was tested against the bacteria E.coli and P. aeruginosa by disc diffusion method using nutrient agar as medium (Table 5). Each of the compound was dissolved in DMSO and solutions of different concentrations $(25,50$ and $100 \mathrm{ppm})$ were prepared separately. In this process, a well was made on agar medium inoculated with microorganism. The well was filled with the test solution using a micropipette and the plate was incubated $24 \mathrm{~h}$ at $37^{\circ} \mathrm{C}$. During this period, the test solution diffused and the growth of the inoculated microorganism was affected. The inhibition zone was developed, at which the concentration was noted.

All of the tested compounds showed good biological activity against microorganism. The bactericidal investigation data of the compounds is summarized in Table 4. A comparative study of the ligands and their transition metal complexes shows that the complexes are more active than the ligands. The increased activity of the metal chelates than those of the ligands is best explained on the basis of overtone's concept and chelation theory.

Table 4. Magnetic moment and molar conductance values of the complexes

\begin{tabular}{ccccc}
\hline S.No. & $\begin{array}{c}\text { Name of the } \\
\text { complex }\end{array}$ & $\begin{array}{c}\text { Magnetic } \\
\text { moment }\end{array}$ & $\begin{array}{c}\text { Molar cond. } \Omega^{1} \mathrm{~cm}^{2} \\
\text { mol }{ }^{1} \text { at room temp., } \\
29{ }^{\circ} \mathrm{C}\end{array}$ & $\begin{array}{c}\text { Molar cond } \Omega^{-1} \mathrm{~cm}^{2} \mathrm{~mol}^{1} \\
\text { at room temp } \pm 10^{\circ} \mathrm{C}, \\
39{ }^{\circ} \mathrm{C}\end{array}$ \\
\hline 1 & $\mathrm{Mn}(\mathrm{PYSC})_{1}(\mathrm{ACSC})_{1}$ & 3.87 & 2.86 & 4.40 \\
2 & $\mathrm{Fe}(\mathrm{PYSC})_{1}(\mathrm{ACSC})_{1}$ & 4.461 & 14.02 & 16.15 \\
3 & $\mathrm{Co}(\mathrm{PYSC})_{1}(\mathrm{ACSC})_{1}$ & 3.997 & 2.56 & 4.34 \\
4 & $\mathrm{Ni}(\mathrm{PYSC})_{1}(\mathrm{ACSC})_{1}$ & 4.61 & 5.25 & 7.35 \\
5 & $\mathrm{Cu}(\mathrm{PYSC})_{1}(\mathrm{ACSC})_{1}$ & 2.02 & 1.50 & 2.95 \\
\hline
\end{tabular}

Table 5. Antibacterial activity data of the ligands and their complexes

\begin{tabular}{ccccccc}
\hline \multirow{2}{*}{$\begin{array}{c}\text { Name of the } \\
\text { ligand/complex }\end{array}$} & \multicolumn{3}{c}{ E.coli } & \multicolumn{4}{c}{ P. aeruginosa } \\
\cline { 2 - 7 } & \cline { 2 - 7 } & Dimeter of inhibition zone in mm. & Dimeter of inhibition zone in mm. \\
\cline { 2 - 7 } & $25 \mathrm{ppm}$ & $50 \mathrm{ppm}$ & $100 \mathrm{ppm}$ & $25 \mathrm{ppm}$ & $50 \mathrm{ppm}$ & $100 \mathrm{ppm}$ \\
\hline $\mathrm{PYSC}$ & 16 & 18 & 20 & 15 & 17 & 20 \\
$\mathrm{ACSC}$ & 20 & 22 & 18 & 13 & 16 & 19 \\
$\mathrm{Mn}(\mathrm{PYSC})_{1}(\mathrm{ACSC})_{1}$ & 24 & 18 & 20 & 23 \\
$\mathrm{Fe}(\mathrm{PYSC})_{1}(\mathrm{ACSC})_{1}$ & 17 & 20 & 22 & 16 & 19 & 22 \\
$\mathrm{Co}(\mathrm{PYSC})_{1}(\mathrm{ACSC})_{1}$ & 18 & 20 & 23 & 19 & 21 & 23 \\
$\mathrm{Ni}(\mathrm{PYSC})_{1}(\mathrm{ACSC})_{1}$ & 18 & 20 & 22 & 18 & 20 & 22 \\
$\mathrm{Cu}(\mathrm{PYSC})_{1}(\mathrm{ACSC})_{1}$ & 22 & 25 & 28 & 20 & 22 & 24 \\
\hline
\end{tabular}




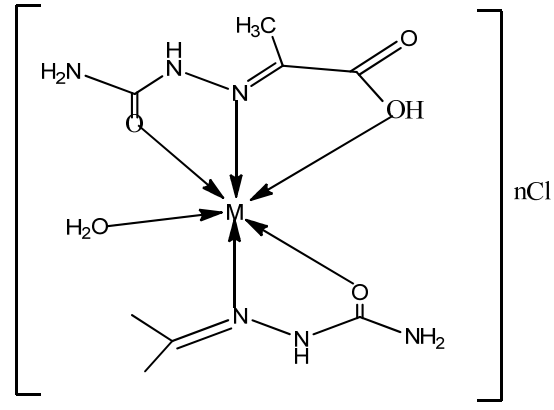

Structure of complexes

\section{Conclusion}

The coordination complexes of $\mathrm{Mn}(\mathrm{II}), \mathrm{Fe}(\mathrm{III}), \mathrm{Co}(\mathrm{II}), \mathrm{Ni}(\mathrm{II})$ and $\mathrm{Cu}(\mathrm{II})$ with tridentate pyruvic acid semicarbazone and bidentate acetone semicarbazone Schiff base ligands were synthesized and characterized. The ligands coordinated with the metals through $\mathrm{N}$ and $\mathrm{O}$ donors. The complexes exhibited octahedral geometry. A comparative study of the MIC value of the ligands and their complexes shows that the chelation might be helpful in tailoring the structure and monitoring the antimicrobial activity and therapeutic potential of a drug. This gives a new thrust area in the field of metallo-drugs (bioinorganic chemistry) through molecular biology.

\section{Acknowledgement}

I am grateful to Principal, Pratap college, Amalner AND the Head Chemistry Department Pratap college, Amalner for laboratory facilities. I am also thankful to the Head Physics Department Pratap College, Amalner for Electronic spectra and IR spectra and Head, SAIF, IIT Mumbai for elemental analysis. I am also thankful to Chairman, UGC, New Delhi for providing financial assistance.

\section{References}

1. Kaim W and Schwederski B, Bioinorganic Chemistry: Inorganic Elements of Life, John Wiley and Sons: London. 1996, 39-262.

2. Xiao-Ming C, Bao Hui Y, Xiao C H and Zhi Tao X J, Chem Soc., Dalton Trans., 1996, 3465-3468.

3. Cotton F A and Wilkinson G. Advanced Inorganic Chemistry, $5^{\text {th }}$ Ed., John Wiley and Sons: New York. 1988, 1358-1371.

4. Greenwood N N, Earnshaw A, Chemistry of the Elements, Pergamon Press: Oxford. 1984, 1392-1420.

5. Crim J and Petering H, Cancer Res., 1967, 27, 1278-1285.

6. Kato M and Muto Y, Coord Chem Rev., 1988, 92, 45-83; DOI:10.1016/00108545(88)85005-7

7. Nagar R. J Inorg Biochem., 1990, 40(4), 349-358; DOI:10.1016/01620134(90)80069-A

8. Patel R N, Singh N, Shukla K K, Gundla V L N and Chauhan U K, Spectrochim Acta, Part A: Molecular Biomolecular Spectr., 2006, 63(1), 21-26; DOI:10.1016/j.saa.2005.04.030

9. $\quad$ Patel K C and Goldberg D E, J Inorganic Nuclear Chem., 1972, 34(2), 637-649; DOI:10.1016/0022-1902(72)80444-5 
10. Abuhijleh A L, Woods C and Ahmed I Y, Inorganica Chimica Acta, 1991, 190(1), 11-17. DOI:10.1016/S0020-1693(00)80226-1

11. Singh D P, Kumar R, Malik V and Tyagi P, Transition Metal Chem.,, 2007, 32(8), 1051- 1055; DOI:10.1007/s11243-007-0279-2

12. Rajendra K Jain and Mishra A P, Current Chem Lett., 2012, 1(4), 163-174.

13. Konig E, Structure and Bonding, 1971, 9, 175-212.

14. Shirode P R and Yeole P M, Chem Sci Trans., 2014, 3(3), 1186-1192;

DOI:10.7598/cst2014.801 